\title{
The Anxiety of Being Asian American: Hate Crimes and Negative Biases During the COVID-19 Pandemic
}

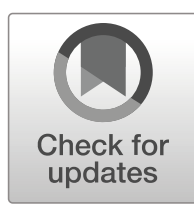

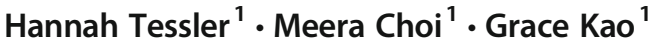 \\ Received: 8 May 2020 / Accepted: 3 June 2020 / \\ Published online: 10 June 2020 \\ (C) Southern Criminal Justice Association 2020
}

\begin{abstract}
In this essay, we review how the COVID-19 (coronavirus) pandemic that began in the United States in early 2020 has elevated the risks of Asian Americans to hate crimes and Asian American businesses to vandalism. During the COVID-19 pandemic, the incidents of negative bias and microaggressions against Asian Americans have also increased. COVID19 is directly linked to China, not just in terms of the origins of the disease, but also in the coverage of it. Because Asian Americans have historically been viewed as perpetually foreign no matter how long they have lived in the United States, we posit that it has been relatively easy for people to treat Chinese or Asian Americans as the physical embodiment of foreignness and disease. We examine the historical antecedents that link Asian Americans to infectious diseases. Finally, we contemplate the possibility that these experiences will lead to a reinvigoration of a panethnic Asian American identity and social movement.
\end{abstract}

Keywords COVID-19 · Hate crime · Asian American · Race $\cdot$ Ethnicity $\cdot$ Racial discrimination $\cdot$ Bias incident $\cdot$ Racialization

\section{Introduction}

COVID-19 (or the coronavirus) is a global pandemic that has affected the everyday lives of hundreds of millions of people. At the time we write this, there have been over four million cases across over 200 countries worldwide (Pettersson, Manley, \& Hern, 2020). Moreover, pervasive stay-at-home orders and calls for social distancing, as well as the disruptions to

Hannah Tessler

hannah.tessler@yale.edu

Meera Choi

meera.choi@yale.edu

Grace Kao

g.kao@yale.edu

1 Department of Sociology, Yale University, 493 College Street, New Haven, CT 06511, USA 
every facet of our lives make it difficult to overstate the importance of COVID-19. As the beginning of the outbreak has been traced to China (and Wuhan in particular), both in the United States and elsewhere, people who are Chinese or seen as East Asian have become associated with this contagious disease. Early reports in the United States were often accompanied by stock photos of Asians in masks (Burton, 2020; Walker, 2020). Many of the first reports labeled the disease as the "Wuhan Virus," or "Chinese Virus," and the Trump administration has also used these terms (Levenson, 2020; Maitra, 2020; Marquardt \& Hansler, 2020; Rogers, Jakes, \& Swanson, 2020; Schwartz, 2020). News media coverage in the United States focused on the hygiene of the seafood market in Wuhan and wild animal consumption as a possible cause of coronavirus (Gomera, 2020; Mackenzie \& Smith, 2020). Memes and jokes about bats and China flooded social media, including posts by our peers online. These reports provide the American public a straightforward narrative that focuses on China as the origin of COVID-19.

In this paper, we review current patterns of hate crimes, microaggressions, and other negative responses against Asian individuals and businesses during the COVID-19 pandemic. These hate crimes and bias incidents occur in the landscape of American racism in which Asian Americans are seen as the embodiment of China and potential carriers of COVID-19, regardless of their ethnicity or generational status. We believe that Asian Americans not only are not "honorary whites," but their very status as Americans is, at best, precarious, and at worst, in doubt during the COVID-19 crisis. We suggest that what we witness today is an extension of the history of Asians in the United States and that this experience may lead to the reemergence of a vibrant panethnic Asian American identity.

\section{Hate Crimes Against Asian Americans During COVID-19}

As of early May 2020, there have been over 1.8 million individuals who have tested positive for and over 105,000 deaths from COVID-19 in the United States alone and the numbers are growing rapidly every day ("Cases in the U.S.," 2020). Although researchers have traced cases of the virus in the United States to travelers from Europe (Gonzalez-Reiche et al., 2020) and to travelers within the United States (Fauver et al., 2020), some members of the general public regard Asian Americans with suspicion and as carriers of the disease. On April 28th, 2020, NBC News reported that $30 \%$ of Americans have personally witnessed someone blaming Asians for the coronavirus (Ellerbeck, 2020).

The COVID-19 pandemic has revealed the negative perceptions of Asian Americans that have long been prevalent in American society. Many individuals in the United States see the virus as foreign and condemn phenotypically Asian bodies as the spreaders of the virus (Ellerbeck, 2020). Consistent with Claire Jean Kim's theory on racial triangulation (Kim, 1999) and the concept of Asians as perpetual foreigners (Ancheta, 2006; Saito, 1997; Tuan, 1998; E. D. Wu, 2015), we posit that during COVID-19, the racial positionality of Asian Americans as foreign and Other persists, and that this pernicious designation may be a threat to the safety and mental health of Asian Americans. They are not only at risk of exposure to COVID-19, but they must contend with the additional risk of victimization, which may increase their anxiety. 
Historically, from the late 19th through the mid twentieth century, popular culture and news media portrayed Asians in America as the "Yellow Peril," which symbolized the Western fear of uncivilized, nonwhite Asian invasion and domination (Okihiro, 2014; Saito, 1997). It is possible that the perceived threat of the Yellow Peril has reemerged in the time of COVID-19.

The spread of the coronavirus and the increased severity of the pandemic has caused fear and panic for most Americans, as COVID-19 has brought about physical restrictions and financial hardships. So far, forty-two states have issued stay-at-home orders, which has resulted in $95 \%$ of the American population facing restrictions that impact their daily lives (Woodward, 2020). Novel efforts to end the pandemic across the states have led businesses to shut down. As a result, more than 30 million people in the United States have filed for unemployment since the onset of the coronavirus crisis (Gura, 2020). Because this virus has been identified as foreign, for some individuals, their feelings have been expressed as xenophobia, prejudice, and violence against Asian Americans. These negative perceptions and actions have gained traction due to the unprecedented impact COVID-19 has on people's lives, and institutions such as UC Berkeley have even normalized these reactions (Chiu, 2020). However, racism and xenophobia are not a "natural" reaction to the threat of the virus; rather, we speculate that the historical legacies of whiteness and citizenship have produced these reactions, where many individuals may interpret Asian Americans as foreign and presenting a higher risk of transmission of the disease.

Already, the FBI has issued a warning that due to COVID-19, there may be increased hate crimes against Asian Americans, because "a portion of the US public will associate COVID-19 with China and Asian American populations" (Margolin, 2020). News reports, police departments, and community organizations have been documenting these incidents. Evidence suggests that the FBI's warning was warranted. Based on reporting from Stop AAPI Hate, in the one-month period from March 19th to April 23rd, there were nearly 1500 alleged instances of anti-Asian bias (Jeung \& Nham, 2020). The reported incidents have been concentrated in New York and California, with $42 \%$ of the reports hailing from California and $17 \%$ of reports from New York, but Asian Americans in 45 states across the nation have reported incidents (Jeung \& Nham, 2020).

\section{Reports of Hate Crimes and Bias Incidents}

There have been a large number of physical assaults against Asian Americans and ethnically Asian individuals in the United States directly related to COVID-19. While the majority of Americans are sheltering-in-place and staying at home, $80 \%$ of the selfreported anti-Asian incidents have taken place outside people's private residences, in grocery stores, local businesses, and public places (Jeung \& Nham, 2020). We suggest that these hate crimes and other incidents of bias have historical roots that have placed Asians outside the boundaries of whiteness and American citizenship. In addition, we believe that the current COVID-19 crisis draws attention to ongoing racial issues and provides a lens through which to challenge the notion of America as a post-racial society (Bonilla-Silva, 2006). 
One of the incidents under investigation as a hate crime includes the attempted murder of a Burmese-American family at a Sam's Club in Midland, Texas (Yam, 2020a). The suspect said that he stabbed the father, a four-year-old child, and a twoyear-old child because he "thought the family was Chinese, and infecting people with coronavirus" (Yam, 2020a). Police are investigating numerous other physical incidents including attacks with acid (Moore \& Cassady, 2020), an umbrella (Madani, 2020), and a $\log$ (Kang, 2020). There have been a number of physical altercations at bus stops (Bensimon, 2020; Madani, 2020), subway stations (Parnell, 2020), convenience stores (Oliveira, 2020), and on the street (Jeung \& Nham, 2020; Sheldon, 2020). Asian Americans are also reporting physical threats being made against them (Driscoll, 2020; Parascandola, 2020). Based on Stop AAPI Hate statistics, 127 Asian Americans filed reports of physical assaults in four weeks (Jeung \& Nham, 2020), and it is likely that other Asians have not reported their experiences out of fear or concern about the legal process.

In addition to the physical attacks and threats against Asian Americans, individuals have also filed reports of vandalism and property damage targeted at Asian businesses. One Korean restaurant in New York City had the graffiti "stop eating dogs" written on its window (Adams, 2020). Perpetrators have also made explicit references to COVID-19 in their vandalism, where phrases such as "take the corona back you ch*nk" (Goodell \& Mann, 2020), and "watch out for corona" (Wang, 2020) have been documented on Asian-owned restaurants. Some of these incidents were not reported to the police and therefore will not be investigated as hate crimes, as business owners reasoned that it would be difficult to track the vandals (Adams, 2020; Buscher, 2020). These incidents of vandalism demonstrate the association some people make between Asian American businesses and COVID-19.

Beyond the narrow definition of the incidents that can be classified as punishable hate crimes, Asian Americans have also documented a large number of alleged bias and hate incidents. Stop AAPI Hate reports indicate that $70 \%$ of coronavirus discrimination against Asian Americans has involved verbal harassment, with over 1000 incidents of verbal harassment reported in just four weeks (Jeung \& Nham, 2020). In addition, there have been over 90 reports of Asian Americans being coughed or spat on. One prevalent theme in the verbal incidents is the linking of Asian bodies to COVID-19, where the aggressors are purportedly calling Asians "coronavirus," "Chinese virus," or "diseased," and telling them that they should "be quarantined," or "go back to China" (ADL 2020). In all of these incidents, the perpetrators consistently use anti-Asian racial slurs (Buscher, 2020; Goodell \& Mann, 2020; Sheldon, 2020). This hateful language that targets all Asians (and not just Chinese Americans) demonstrates the racialization of Asian Americans.

The threat of a global pandemic to people's everyday lives is something that most Americans have not experienced before. However, the act of interpreting the current national crisis as an external threat and ascribing this danger to Chinese bodies and more broadly Asian bodies should not surprise scholars of Asian Americans. In fact, this deeply-rooted cognitive association of Asian Americans to Asia and to disease has a long history. Hence, we examine the phenomenon of xenophobia against Asian Americans in the context of historical racial dynamics in the United States. 


\section{The Color Line and the Positionality of Asian Americans}

Race has been posited as a socio-historical concept, and while many race scholars in the United States have focused on the black/white binary, others have documented how Asian Americans have also been racialized over time (Omi \& Winant, 2014). These scholars have examined how the racialization of Asian Americans has developed in relation to African Americans and white Americans (Bonilla-Silva, 2004; Kim, 1999). One of the dominant stereotypes of Asian Americans is that they are perpetual foreigners, where individuals directly link phenotypical Asian ethnic appearance with foreignness, regardless of Asian immigrant or generational status (Ancheta, 2006; Tuan, 1998; F. H. Wu, 2002). This stereotype is longstanding in American history and has forcefully re-emerged during the COVID-19 crisis. The perception of an Asianlooking person as simultaneously Chinese, Asian, and foreign underscores how this racial categorization affects all Asian Americans. Thus, we suggest that the concept of Asian American panethnicity (Okamoto \& Mora, 2014) may be particularly applicable during the COVID-19 pandemic.

The legacy of white supremacy equates white bodies with purity and innocence, while nonwhite bodies are designated as unclean, uncivilized, and dangerous. White supremacy and its tactic of othering Asian bodies has been a consistent recurrence over earlier pandemics. Dating back to the nineteenth century, the bubonic plague was framed as a "racial disease" which only Asian bodies could be infected by whereas white bodies were seen as immune (Randall, 2019). In 1899, Honolulu officials quarantined and burned Chinatown as a precaution against the bubonic plague (Mohr, 2004). In 1900, San Francisco authorities quarantined Chinatown residents, and regulated food and people in and out of Chinatown, believing that the unclean food and Asian people were the cause of the epidemic (Shah, 2001; Trauner, 1978). The history of the Yellow Peril has continued throughout the 20th and 21st centuries in the embodied perceptions of Asian immigrants as the spreaders of disease (Molina, 2006).

More recently, during the 2003 SARS (Severe Acute Respiratory Syndrome) epidemic, the discourse in the United States focused on Chinatown as the epicenter of the disease (Eichelberger, 2007). Studies suggest that $14 \%$ of Americans reported avoiding Asian businesses and Asian Americans experienced increased threat and anxiety during SARS (Blendon, Benson, DesRoches, Raleigh, \& Taylor-Clark, 2004). We suspect the negative impact of COVID-19 on Asian Americans has been far greater than the impact of SARS. In New York City's Chinatown, restaurants suffered immediately after the first reports of COVID-19, as some restaurants and businesses experienced up to an $85 \%$ drop in profits for the two months prior to March 16th, 2020 - far before any stayat-home orders were given (Roberts, 2020). When moral panic arises, foreign bodies, typically the undesirable and "un-American" yellow bodies, may be seen as a threat that can harm pure white bodies.

The cycle of elevated risk, followed by fearing and blaming what is foreign is not just limited to disease outbreaks, but also occurs during economic downturns. In 1982, Vincent Chin was beaten to death by two men who blamed him for the influx of Japanese cars into the United States auto market. Vincent Chin was attacked with racial slurs and specifically targeted because of his race. Although Chin was Chinese American, in the minds of these two men, he represented the downturn of the auto industry in Detroit and the increased imports of Japanese automobiles (Choy \& Tajima-Pena, 1987). 
Similarly, after the 9/11 attacks in the United States, retaliatory aggressions were not limited to attacks against Arabs or Muslims (Perry, 2003). Violence and hatred against the perceived enemy resulted in incidents targeting Sikhs, second and third generation Indian Americans, and even Lebanese and Greeks (Perry, 2003). More recently, the hate crime murder of Srinivas Kuchibhotla, an Indian immigrant falsely assumed to be an Iranian terrorist and told "get out of my country" before being shot to death, illustrates the association between racialized perceptions of threat and incidents of violence (Fuchs 2018). With the COVID-19 pandemic, violent attacks and racial discrimination against Asian Americans have emerged as non-Asian Americans look for someone or something Asian to blame for their anger and fear about illness, economic insecurity, and stay-at-home orders.

\section{Fear and the Mental Health of Asian Americans}

The current perceptions of China and more broadly East Asia as both economic and public health threats have made Chinese and East Asians in America fearful for their own safety. Some Asian Americans have made efforts to hide their Asian identity or assert their status as American in an attempt to prevent hate crime attacks (Buscher, 2020; Tang, 2020). While this tactic may be effective on the individual level, it does not modify the positionality of Asian bodies during COVID-19. The attempt to distinguish Asian Americans from Asians who are foreign nationals misses the fact that in the United States, being Asians and being foreign are inextricably bound together.

After World War II, news media and local organizations encouraged Chinese Americans to distinguish themselves from the Japanese, and similarly encouraged Japanese Americans to show their Americanness and patriotism to gain acceptance by the white majority (E. D. Wu, 2015). Muslim and Sikh Americans displayed American flags after $9 / 11$ to show that they were not a threat to the United States, and more recently there has been a movement to celebrate Sikh Captain America (Ishisaka, 2018). Former presidential candidate Andrew Yang suggested that Asian Americans fight against racism by wearing red white and blue and prominently displaying their Americanness (Yang, 2020). In many of these situations, these strategies did not directly address the problems of racism and xenophobia - they simply shifted the blame towards another group.

Disease does not differentiate among people based on skin color or national origin, yet many Asian Americans have suffered from discrimination and hatred during the COVID-19 pandemic. Although the threat of the virus is real for all Americans, Asian Americans bear the additional burden of feeling unsafe and vulnerable to attack by others. The link between COVID-19 and hate crimes and bias incidents against Asian Americans is indicative of the widespread racial sentiments which continue to be prominent in American society. While some scholars have gone as far as to regard Asian Americans as "honorary whites" (Tuan, 1998), the current COVID-19 crisis has made markedly clear this is an illusion, at best. There are a number of reasons why the racial dynamics of anti-Asian crimes during COVID-19 should be examined more closely.

First, the majority of incidents and attacks have occurred in diverse metropolitan areas such as New York City, Boston, and Los Angeles. These are spaces that most 
Americans have traditionally regarded as more liberal and tolerant of difference than other parts of the United States. In New York City alone, from the start of the COVID19 outbreak through April 2020, the NYPD's hate crime task force has investigated fourteen cases where all the victims were Asian and targeted due to coronavirus discrimination (NYPD, 2020). The remarks of a Kansas governor that said his town was safe "because it had only a few Chinese residents" (Lefler \& Heying 2020) offers one explanation for the high concentration of racial incidents in large cities with sizable Asian populations, but we think that this is not sufficient in explaining the data so far. Future research should track racial bias and hate crimes more systematically in order to further our understanding of how demography and urbanicity influence these incidents.

Second, these hate crimes have increased the anxiety of Asian Americans during already uncertain times, with many fearful for their physical safety when running everyday errands (Tavernise \& Oppel Jr., 2020). Asian Americans are now self-conscious about "coughing while Asian" (Aratani, 2020), and concerned about being targeted for hate crimes (Liu, 2020; Wong, 2020). There is evidence to suggest that Asian Americans under-report crimes (Allport, 1993), and some recent immigrants may lack an understanding of the legal system and process of reporting crimes, particularly in the case of hate crimes. Therefore, scholars should take additional care to document and analyze these incidents and their effects on Asian American communities across the United States.

The possible upward trend of anti-Asian bias incidents and hate crimes is indicative of the growth of white nationalism and xenophobia. The image of a disease carrier with respect to COVID-19 is bound in Asian bodies and includes assumptions about race, ethnicity, and citizenship. As Vincent Chin, Srinivas Kuchibhotla, the Burmese-American family, and many others have shown us, the level of fungibility in terms of how Asian ethnicities are perceived can be deadly. It does not matter if the person is from China, of Chinese origin, or simply looks Asian - the perpetrators of this violence see all of these bodies as foreign and threatening. While there have been numerous instances of anti-Asian bias and crime, there have not been similarly patterned anti-European tourist incidents or an avoidance of Italian restaurants, suggesting that COVID-19 illuminates the particular racialization of disease that extends beyond this virus, and further back in American history.

Already there has been substantial news coverage of these anti-Asian crimes, which suggests that people are paying attention to this issue, and police departments are actively investigating many of these incidents. Activists and community organizations have started online campaigns such as \#washthehate and \#hateisavirus to combat anti-Asian racism during this time. The $\mathrm{BBC}$ has documented 120 distinct news articles covering alleged incidents of discrimination since the onset of the COVID-19 pandemic (Cheung, Feng, \& Deng, 2020). In addition, the Chinese for Affirmative Action and Asian Pacific Policy and Planning Council have created a platform where individuals can record incidents of racism and coronavirus discrimination. The reporting of hate crimes during COVID-19 is superior to the reports of these types of incidents during the SARS outbreak (Leung Coleman, 2020; Washer, 2004). Although the federal government response has been limited compared to the hate crime prevention initiatives after 9/11 and SARS, in May 2020, the Commission on Civil Rights agreed to take on the demands proposed by a group of Democratic Senators in a letter requesting a stronger response to the anti-Asian hate crimes and discrimination during COVID-19 (Campbell \& Ellerbeck, 2020; Yam, 2020b).

Similar to the murder of Vincent Chin, which served to ignite an Asian American activist movement, we hypothesize that the racial incidents against Asian Americans 
during the COVID-19 pandemic may encourage the political mobilization of a panethnic Asian American movement. At the same time, we believe that the incidents that are classified as "hate crimes" and "bias incidents" based on legal definitions do not fully capture the extent or pervasiveness of racist and xenophobic thoughts against Asian Americans. We encourage future scholars to more closely examine the culturally embedded racial logics that lead to these incidents, rather than focusing solely on the incidents themselves as the object of analysis. The hate crimes against Asians in the time of COVID-19 highlight the ways that Asian Americans continue to be viewed as foreign and suspect. This may be an additional burden on Asian Americans beyond the anxiety, economic instability, and the risk of illness all Americans have experienced during COVID-19.

Acknowledgements We gratefully acknowledge support from the Faculty of Arts and Sciences, the MacMillan Center, and the Council for East Asia at Yale University. We are also grateful for the support of the Laboratory Program for Korean Studies through the Ministry of Education of the Republic of Korea and the Korean Studies Promotion Service of the Academy of Korean Studies (AKS-2016-LAB-2250002).

\section{References}

Adams, E. (2020). Racist graffiti scrawled on Michelin-starred West Village Korean restaurant JeJu. Eater NY. https://ny.eater.com/2020/4/13/21218921/jeju-noodle-bar-racist-graffiti-harrasment-coronavirusnyc. Accessed 26 Apr 2020.

ADL. (2020). Reports of anti-Asian assaults, harassment and hate crimes rise as coronavirus spreads. AntiDefamation League. https://www.adl.org/blog/reports-of-anti-asian-assaults-harassment-and-hate-crimesrise-as-coronavirus-spreads. Accessed 26 Apr 2020.

Allport, G. (1993). Racial violence against Asian Americans. Harvard Law Review, 106(8), 1926-1943. https://doi.org/10.2307/1341790.

Ancheta, A. N. (2006). Race, rights, and the Asian American experience. New Brunswick: Rutgers University Press.

Aratani, L. (2020). "Coughing while Asian": Living in fear as racism feeds off coronavirus panic. The Guardian. https://www.theguardian.com/world/2020/mar/24/coronavirus-us-asian-americans-racism . Accessed 27 Apr 2020.

Bensimon, O. (2020). Cops bust suspect accused of coronavirus-related hate crime on Asian Man. New York Post. https:/nypost.com/2020/03/14/cops-bust-suspect-in-coronavirus-related-hate-crime-on-asian-man/. Accessed 26 Apr 2020.

Blendon, R. J., Benson, J. M., DesRoches, C. M., Raleigh, E., \& Taylor-Clark, K. (2004). Public's response to severe acute respiratory syndrome in Toronto and the United States. Clinical Infectious Diseases, 38(7), 925-931. https://doi.org/10.1086/382355.

Bonilla-Silva, E. (2004). From bi-racial to tri-racial: Towards a new system of racial stratification in the USA. Ethnic and Racial Studies, 27(6), 931-950. https://doi.org/10.1080/0141987042000268530.

Bonilla-Silva, E. (2006). Racism without racists: Color-blind racism and the persistence of racial inequality in the United States. Lanham: Rowman \& Littlefield Publishers.

Burton, N. (2020). Why Asians in masks should not be the "face" of the coronavirus. Vox. https://www.vox. com/identities/2020/3/6/21166625/coronavirus-photos-racism. Accessed 6 May 2020.

Buscher, R. (2020). Reality is hitting me in the face: Asian Americans grapple with racism due to COVID-19. WHYY. https://whyy.org/articles/reality-is-hitting-me-in-the-face-asian-americans-grapple-with-racismdue-to-covid-19/. Accessed 26 Apr 2020.

Campbell, A. F., \& Ellerbeck, A. (2020). Federal agencies are doing little about the rise in anti-Asian hate. NBC News. https://www.nbcnews.com/news/asian-america/federal-agencies-are-doing-little-about-riseanti-asian-hate-n1184766. Accessed 29 May 2020.

Cases in the U.S. (2020). https:/www.cdc.gov/coronavirus/2019-ncov/cases-updates/cases-in-us.html. Accessed 2 Jun 2020. 
Cheung, H., Feng, Z., \& Deng, B. (2020). Coronavirus: What attacks on Asians reveal about American identity. BBC News. https:/www.bbc.com/news/world-us-canada-52714804. Accessed 29 May 2020.

Chiu, A. (2020). UC Berkeley apologizes for coronavirus post listing xenophobia under 'normal reactions' to the outbreak. The Washington Post. https://www.washingtonpost.com/nation/2020/01/31/berkeleycoronavirus-xenophobia/. Accessed 2 Jun 2020.

Choy, C., \& Tajima-Pena, R. (1987). Who killed Vincent Chin? http:/www.imdb.com/title/tt0096440/. Accessed 2 Jun 2020.

Driscoll, E. (2020). Update: Racist death threats lodged against Seymour restaurant. Valley Independent Sentinel. https://valley.newhavenindependent.org/archives/entry/update_racist_death_threats_lodged_ against_seymour_restaurant/. Accessed 26 Apr 2020.

Eichelberger, L. (2007). SARS and New York's Chinatown: The politics of risk and blame during an epidemic of fear. Social Science \& Medicine, 65(6), 1284-1295. https://doi.org/10.1016/j.socscimed.2007.04.022.

Ellerbeck, A. (2020). Over 30 percent of Americans have witnessed COVID-19 bias against Asians, poll says. NBC News. https://www.nbcnews.com/news/asian-america/over-30-americans-have-witnessed-covid-19bias-against-asians-n1193901. Accessed 6 May 2020.

Fauver, J. R., Petrone, M. E., Hodcroft, E. B., Shioda, K., Ehrlich, H. Y., Watts, A. G., Vogels, C. B. F., Brito, A. F., Alpert, T., Muyombwe, A., Razeq, J., Downing, R., Cheemarla, N. R., Wyllie, A. L., Kalinich, C. C., Ott, I., Quick, J., Loman, N. J., Neugebauer, K. M., et al. (2020). Coast-to-coast spread of SARS-CoV2 in the United States revealed by genomic epidemiology [Preprint]. Public and Global Health. https://doi. org/10.1101/2020.03.25.20043828.

Fuchs, C. (2018). Kansas man sentenced to life for killing Indian engineer in a bar. NBC News. https://www. nbcnews.com/news/asian-america/kansas-man-sentenced-life-prison-hate-crime-shooting-n898361. Accessed 2 Jun 2020.

Gomera, M. (2020). How to prevent outbreaks of zoonotic diseases like COVID-19. Aljazeera. https://www. aljazeera.com/indepth/opinion/prevent-outbreaks-zoonotic-diseases-covid-19-200404130822685.html. Accessed 26 Apr 2020.

Gonzalez-Reiche, A. S., Hernandez, M. M., Sullivan, M., Ciferri, B., Alshammary, H., Obla, A., Fabre, S., Kleiner, G., Polanco, J., Khan, Z., Alburquerque, B., van de Guchte, A., Dutta, J., Francoeur, N., Melo, B. S., Oussenko, I., Deikus, G., Soto, J., Sridhar, S. H., ... van Bakel, H. (2020). Introductions and early spread of SARS-CoV-2 in the New York City area. [Preprint]. MedRxiv. https://doi.org/10.1101 /2020.04.08.20056929

Goodell, E., \& Mann, D. (2020). Take the corona back you ******: Yakima police investigate racist graffiti at Asian buffet. Yaktri News. https:/www.yaktrinews.com/take-the-corona-back-you-yakima-policeinvestigate-racist-graffiti-at-asian-buffet/. Accessed 26 Apr 2020.

Gura, D. (2020). U.S. jobless claims reach 26 million since coronavirus hit, wiping out all gains since 2008 recession. NBC News. https://www.nbcnews.com/business/business-news/u-s-jobless-claims-reach-26million-coronavirus-hit-wiping-n1190296. Accessed 27 Apr 2020.

Ishisaka, N. (2018). Sikh Captain America fights intolerance and bigotry. The Seattle Times. https://www.seattletimes. com/entertainment/sikh-captain-america-fights-intolerance-and-bigotry/. Accessed 6 May 2020.

Jeung, R., \& Nham, K. (2020). Incidents of coronavirus-related discrimination. Retrieved from http://www. asianpacificpolicyandplanningcouncil.org/wp-content/uploads/STOP_AAPI_HATE_MONTHLY_ REPORT_4_23_20.pdf. Accessed 6 May 2020.

Kang, E. Y.J. (2020). Asian Americans feel the bite of prejudice during the COVID-19 pandemic. NPR.Org. https://www.npr.org/local/309/2020/03/31/824397216/asian-americans-feel-the-bite-of-prejudice-duringthe-c-o-v-i-d-19-pandemic. Accessed 27 Apr 2020.

Kim, C. J. (1999). The racial triangulation of Asian Americans. Politics and Society, 27(1), 105-138. https://doi.org/10.1177/0032329299027001005.

Lefler, D., \& Heying, T. (2020). Kansas official: Pandemic isn't a problem here because there are few Chinese people. The Kansas City Star. https:/www.kansascity.com/opinion/editorials/article241353836.html. Accessed 27 Apr 2020.

Leung Coleman, M. (2020). Coronavirus is inspiring anti-Asian racism: This is our political awakening. The Washington Post. https:/www.washingtonpost.com/outlook/2020/03/25/coronavirus-is-inspiring-antiasian-racism-this-is-our-political-awakening/. Accessed 2 Jun 2020.

Levenson, T. (2020). Stop trying to make "Wuhan virus" happen. The Atlantic. https://www.theatlantic. com/ideas/archive/2020/03/stop-trying-make-wuhan-virus-happen/607786/. Accessed 26 Apr 2020.

Liu, C. (2020). Being Asian American in the time of COVID-19. The Daily Nexus. http://dailynexus. com/2020-04-21/being-asian-american-in-the-time-of-covid-19/. Accessed 27 Apr 2020. 
Mackenzie, J. S., \& Smith, D. W. (2020). COVID-19: A novel zoonotic disease caused by a coronavirus from China: What we know and what we don't. Microbiology Australia, 41(1), 45-50. https://doi.org/10.1071 /MA20013.

Madani, D. (2020). Woman needed stitches after anti-Asian hate crime attack on city bus, NYPD says. NBC News. https:/www.nbcnews.com/news/asian-america/woman-needs-stitches-after-anti-asian-hate-crimeattack-city-n1177146?fbclid=IwAR2ZRdKsLW7ksNaIt3SVdP_T4zNEk125CLWbNsLRJA1E9 EwoRpD32wbO0GU. Accessed 26 April 2020.

Maitra, S. (2020). The Wuhan virus is finally awakening Europe to China's imperialism. The Federalist. https://thefederalist.com/2020/04/21/the-wuhan-virus-is-finally-awakening-europe-to-chinasimperialism/. Accessed 27 Apr 2020.

Margolin, J. (2020). FBI warns of potential surge in hate crimes against Asian Americans amid coronavirus. $A B C$ News. https://abcnews.go.com/US/fbi-warns-potential-surge-hate-crimes-asianamericans/story?id=69831920. . Accessed 26 April 2020

Marquardt, A., \& Hansler, J. (2020). US push to include "Wuhan virus" language in G7 joint statement fractures alliance. CNN Politics. https:/www.cnn.com/2020/03/25/politics/g7-coronavirusstatement/index.html. Accessed 2 Jun 2020.

Mohr, J. C. (2004). Plague and fire: Battling black death and the 1900 burning of Honolulu's Chinatown. Oxford: Oxford University Press.

Molina, N. (2006). Fit to be citizens? Public health and race in Los Angeles, 1879-1939. Berkeley: University of California Press.

Moore, T., \& Cassady, D. (2020). Brooklyn woman burned outside home in possible acid attack. New York Post. https://nypost.com/2020/04/06/brooklyn-woman-burned-outside-home-in-possible-acid-attack/. Accessed 26 April 2020.

NYPD. (2020). NYPD Announces citywide crime statistics for April 2020. New York City Police Department. http://www1.nyc.gov/site/nypd/news/p0504a/nypd-citywide-crime-statistics-april-2020. Accessed 7 May 2020.

Okamoto, D., \& Mora, G. C. (2014). Panethnicity. Annual Review of Sociology, 40(1), 219-239. https://doi. org/10.1146/annurev-soc-071913-043201.

Okihiro, G. Y. (2014). Margins and mainstreams: Asians in American history and culture. Seattle: University of Washington Press.

Oliveira, N. (2020). Brute attacks, shouts at Asian man, 92, in Vancouver. New York Daily News. https:/www.nydailynews.com/news/crime/ny-vancouver-hate-crime-brute-attacks-shouts-at-elderlyasian-man-20200424-wyr66kgierf55obk5cx6yeusci-story.html . Accessed 26 April 2020.

Omi, M., \& Winant, H. (2014). Racial formation in the United States. New York: Routledge.

Parascandola, R. (2020). Asian man spit on, threatened in NYC coronavirus hate crime. New York Daily News. https:/www.nydailynews.com/coronavirus/ny-coronavirus-hate-crime-brooklyn-subway-spit20200325-h4w4nzb74fbadpx6li4f7xdoc4-story.html . Accessed 26 April 2020.

Parnell, W. (2020). Coronavirus-inspired crook robs woman of cellphone, spews hate. New York Daily News. https:/www.nydailynews.com/coronavirus/ny-coronavirus-cellphone-robbery-hate-crime-brooklynsubway-20200322-ufznc24nybcencdtja2ycbsx2i-story.html . Accessed 26 April 2020.

Perry, B. (2003). Hate and bias crime: A reader. New York: Routledge.

Pettersson, H., Manley, B., \& Hern, S. (2020). Tracking coronavirus' global spread. CNN. https://www.cnn. com/interactive/2020/health/coronavirus-maps-and-cases . Accessed 29 May 2020.

Randall, D. K. (2019). Black death at the Golden Gate: The race to save America from the bubonic plague. New York: W.W. Norton.

Roberts, N. (2020). As COVID-19 spreads, Manhattan's Chinatown contemplates a bleak future. Marketplace. https://www.marketplace.org/2020/03/16/as-covid-19-spreads-manhattans-chinatowncontemplates-a-bleak-future/. Accessed 6 May 2020

Rogers, K., Jakes, L., \& Swanson, A. (2020). Trump defends using 'Chinese virus' label, ignoring growing criticism. The New York Times. https://www.nytimes.com/2020/03/18/us/politics/china-virus.html . Accessed 27 April 2020.

Saito, N. T. (1997). Model minority, yellow peril: Functions of foreignness in the construction of Asian American legal identity. Asian Law Journal, 4, 71.

Schwartz, I. (2020). Media called coronavirus "Wuhan" or "Chinese Coronavirus" dozens of times. Real Clear Politics. https://www.realclearpolitics.com/video/2020/03/12/media_called_coronavirus_wuhan_ or_chinese_coronavirus_dozens_of_times.html. Accessed 27 April 2020.

Shah, N. (2001). Contagious divides. Berkeley: University of California Press.

Sheldon, C. (2020). Girl charged with racially assaulting Asian woman over coronavirus. NJ.Com. https:/www.nj.com/coronavirus/2020/04/girl-charged-with-racially-assaulting-asian-woman-over- 
coronavirus.html?utm_content=nj_twitter_njdotcom\&utm_source=twitter\&utm_campaign=njdotcom_ sf\&utm_medium=social. Accessed 26 Apr 2020.

Tang, T. (2020). From guns to GoPros, Asian Americans seek to deter attacks. WGME. https://wgme. $\mathrm{com} /$ news/nation-world/from-guns-to-gopros-asian-americans-seek-to-deter-attacks-04-24-2020. Accessed 7 May 2020.

Trauner, J. B. (1978). The Chinese as medical scapegoats in San Francisco, 1870-1905. California History, 57(1), 70-87. https://doi.org/10.2307/25157817.

Tuan, M. (1998). Forever foreigners or honorary whites? The Asian ethnic experience today. New Brunswick: Rutgers University Press.

Walker, A. (2020). News outlets contribute to anti-Asian racism with careless stock photos on coronavirus coverage. Media Matters for America. https://www.mediamatters.org/coronavirus-covid-19/newsoutlets-contribute-anti-asian-racism-careless-stock-photos-coronavirus. Accessed 6 May 2020.

Wang, J. (2020). Vandals tag downtown Asian restaurant with racist message. KOB4. https://www.kob. com/coronavirus/vandals-tag-downtown-asian-restaurant-with-racist-message/5677160/. Accessed 27 Ap 2020.

Washer, P. (2004). Representations of SARS in the British newspapers. Social Science \& Medicine, 59(12), 2561-2571. https://doi.org/10.1016/j.socscimed.2004.03.038.

Wong, B. (2020). For Asian Americans, there are two pandemics: COVID-19 and daily bigotry. Huffington Post. https://www.huffpost.com/entry/asian-american-racism-coronavirus_1_5e790a71c5b63c3b64954 eb4 . Accessed 27 April 2020.

Secon, H., \& Woodward, A. (2020, April 7). About 95\% of Americans have been ordered to stay at home. This map shows which cities and states are under lockdown. Business Insider.https://www. businessinsider.com/us-map-stay-at-home-orders-lockdowns-2020-3. Accessed 26 April 2020.

Wu, E. D. (2015). The color of success: Asian Americans and the origins of the model minority. Princeton: Princeton University Press.

Wu, F. H. (2002). Where are you really from? Asian Americans and the perpetual foreigner syndrome. Civil Rights Journal, 6(1), 14+. Accessed 2 June 2020.

Yam, K. (2020a). UC Berkeley health account calls xenophobia a "common reaction" to coronavirus. $N B C$ News. https://www.nbcnews.com/news/asian-america/uc-berkeley-health-account-calls-xenophobiacommon-reaction-coronavirus-n1127271. Accessed 26 April 2020.

Yam, K. (2020b). Civil rights commission agrees to senate Democrats' call for action against anti-Asian racism. NBC News. https://www.nbcnews.com/news/asian-america/civil-rights-commission-agreessenate-democrats-call-action-against-anti-n1207136?fbclid=IwAR3vsE3rCMg7hsjBCnBswa_95 LRVyjfIIf27y3j_wKuxWafkhUtcVXGvOXM. Accessed 29 May 2020.

Yang, A. (2020). Andrew Yang: We Asian Americans are not the virus, but we can be part of the cure. Washington Post. https://www.washingtonpost.com/opinions/2020/04/01/andrew-yang-coronavirusdiscrimination/. Accessed 26 Apr 2020.

Publisher's Note Springer Nature remains neutral with regard to jurisdictional claims in published maps and institutional affiliations.

Hannah Tessler is a $\mathrm{PhD}$ student in Sociology at Yale University. Her research focuses on race, ethnicity, and sociology of education.

Meera Choi is a $\mathrm{PhD}$ student in Sociology at Yale University. Her research focuses on the intersection of family and culture.

Grace Kao is Chair and IBM Professor of Sociology and Faculty Director of Education Studies at Yale University. She is the immediate past Vice President of the American Sociological Association. Her research focuses on race, ethnicity, immigrant adaptation, Asian Americans, adolescence, and sociology of education. 